\title{
Low Temperature Plasma Jets: Characterization and Biomedical Applications ${ }^{\dagger}$
}

\author{
Mounir Laroussi \\ Electrical \& Computer Engineering Department, Old Dominion University, Norfolk, VA 23529, USA; \\ mlarouss@odu.edu \\ + This editorial is for the upcoming ebook 'Cold Plasma: Characteristics and Applications in Medicine'.
}

Received: 14 March 2020; Accepted: 14 March 2020; Published: 3 April 2020

For many decades non-equilibrium plasmas (NEPs) that can be generated at atmospheric pressure have played important roles in various material and surface processing applications. Although there are many methods to generate NEPs, one of the simplest and most practical ways is to use the dielectric barrier discharge (DBD) configuration. This discharge uses a dielectric to cover at least one of two electrodes. The plasma generated in the gap between electrodes is generally filamentary, but under some conditions can be uniformly diffuse. Extensive research work has been done on DBD, and one of its earliest applications was to generate ozone for the cleaning of water supplies [1-4]. DBD has also gained widespread use in biomedical applications since the mid 1990s, when it was demonstrated that the plasma produced by DBD possesses strong germicidal properties [5]. However, because the plasma is confined to the gap between electrodes, the use of the conventional DBD setup in biomedical applications has remained limited. This situation changed when investigators reported that with proper design the plasma can be "blown" out of the discharge gap and into the ambient air [6,7]. This development has opened up all kind of possibilities to use this plasma arrangement for medical applications. This is because the plasma can be made available completely out of the ignition region and launched via a nozzle into ambient air. Therefore, it can be aimed at a specific location (such as a wound) and applied for a certain length of time to achieve a biological outcome. Since all this can be done at atmospheric pressure and in ambient air it has become possible to treat actual patients with such plasma generation schemes. These devices have come to be known as non-equilibrium atmospheric pressure plasma jets (N-APPJ).

The first applications of N-APPJs were in material processing. Using various operating conditions and gases, they were found to increase the wettability of polypropylene (PP) and polyethylene terephthalate (PET) films [8]; to degrade aromatic rings of dies such methyl violet [9]; to etch silicon and $\mathrm{Si}$ (100); to ash photoresist at a rate greater than $1.2 \mu \mathrm{m} / \mathrm{min}$ [10]; to deposit silicon dioxide, $\mathrm{SiO}_{2}$, and films on various substrates at deposition rates greater than $10 \mathrm{~nm} / \mathrm{s}$; and so on. However, the biomedical applications of N-APPJs only surged after the first "bio-tolerant" plasma jets were reported in the mid-2000s $[6,7,11]$. Today these plasma jets and other plasma sources are being extensively researched for medical applications ranging from wound healing to dentistry and cancer therapy [12-27].

Around 2005, investigators at Old Dominion University, USA, and the University of Wuppertal, Germany, independently discovered that the plasma plumes of N-APPJs were in fact not continuous but made of fast-propagating discrete small volumes of plasma (known as "plasma bullets") $[28,29]$. This has led to numerous experimental and modeling works aimed at elucidating the mechanisms of ignition and propagation of N-APPJs [30-34]. Recently it was well established that these jets are enabled by guided ionization waves where photoionization and the electric field at the head of the ionization front play important roles [35]. The magnitude of the electric field was measured by several investigators and was found to be in the $10-30 \mathrm{kV} / \mathrm{cm}$ range [36-38]. 
Various power-driving methods have been used to ignite and sustain N-APPJs. These include $\mathrm{DC}$, pulsed DC, RF, and microwave power [7]. Because they provide interesting reactive chemistry, $\mathrm{N}$-APPJs play an ever-increasing role in biomedicine. Reactive oxygen species (ROSs) and reactive nitrogen species (RNSs) such as $\mathrm{O}, \mathrm{OH}, \mathrm{O}_{2}^{-},{ }^{1} \mathrm{O}_{2}, \mathrm{H}_{2} \mathrm{O}_{2}, \mathrm{NO}$, and $\mathrm{NO}_{2}$, which are generated by these plasma jets, have been shown to play a central role in their interactions with liquids and soft matter, including cells and tissues [39-42]. Based on these results it has been concluded that the biological effects of these plasmas are mostly mediated by the ROSs and RNSs they produce. These reactive molecules (radical and non-radical) can oxidize membranes' lipids and proteins and can trigger and/or modulate cell signaling. Depending on the type and concentration of ROS and RNS, proliferation or destruction of cells can occur. Many investigators have reported that low temperature plasma can be tailored to induce apoptosis in cancer cells without causing damage to healthy cells [43-45]. It is also suspected that the high electric field at the head of plasma plumes can cause electroporation, letting ROS and RNS molecules into the interior of the cells. These can then cause various deleterious effects including DNA strand breaks and mitochondrial damage.

This book is a compilation of two special issues guest edited by Dr. Mounir Laroussi for the journal Plasma. The two special issues are: (1) Low Temperature Plasma Jets: Physics, Diagnostics, and Applications; (2) Plasma Medicine. This book is therefore organized into two parts. The first part is a collection of six papers published in the special issues on plasma jets that discuss the design of plasma jets such the Cooperation in Science and Technology (COST) plasma jets [46], the interaction of plasma jets with various targets [47-49], characterizations of plasma jets, treatments of water by a plasma jet [50], and the use of a plasma jet as a source of guided ionization waves to ignite a large volume plasma in an electrodeless chamber [51]. The second part of the book is a collection of 8 papers published in the special issue on plasma medicine. The first paper is an introductory review of the field of plasma medicine [52]; some of the following papers discuss the applications of various plasma jets for cancer treatment, including triple-negative breast cancer cells, ovarian cancer cells, and the manner in which plasma can decrease the viability of malignant solid tumors cells [53-55]. One paper presents a performance evaluation of three plasma sources/jets [56], while two other papers discuss how plasma modulates the responsiveness of human macrophages and cellular glucose uptake $[57,58]$. Finally, the issue concludes with a review paper discussing how low temperature plasma offers a new hope for cancer treatment [59].

Conflicts of Interest: The author declares no conflict of interest.

\section{References}

1. Von Siemens, W. Ueber die elektrostatische Induction und die Verzögerung des Stroms in Flaschendrähten. Ann. Phys. Chem. 1857, 12, 66. [CrossRef]

2. Kogelschatz, U. Silent discharges for the generation of ultraviolet and vacuum ultraviolet excimer radiation. Pure Appl. Chem. 1990, 62, 1667. [CrossRef]

3. Kogelschatz, U.; Eliasson, B.; Egli, W. Dielectric barrier discharges: Principle and applications. J. Phys. 1997, C4, 47. [CrossRef]

4. Kogelschatz, U. Filamentary, patterned, and diffuse barrier discharges. IEEE Trans. Plasma Sci. 2002, 30, 1400. [CrossRef]

5. Laroussi, M. Sterilization of contaminated matter with an atmospheric pressure plasma. IEEE Trans. Plasma Sci. 1996, 24, 1188. [CrossRef]

6. Laroussi, M.; Lu, X. Room temperature atmospheric pressure plasma plume for biomedical applications. Appl. Phys. Lett. 2005, 87, 113902. [CrossRef]

7. Laroussi, M.; Akan, T. Arc-free atmospheric pressure cold plasma jets: A review. Plasma Process. Polym. 2007, 4, 777. [CrossRef]

8. Cheng, C.; Liye, Z.; Zhan, R. Surface modification of polymer fiber by the new atmospheric pressure cold plasma jet. Surf. Coat. Technol. 2006, 200, 6659. [CrossRef] 
9. Chen, G.; Chen, S.; Zhou, M.; Feng, W.; Gu, W.; Yang, S. The preliminary discharging characterization of a novel APGD plume and its application in organic contaminant degradation. Plasma Sources Sci. Technol. 2006, 15, 603. [CrossRef]

10. Inomata, K.; Koinuma, H.; Oikawa, Y.; Shiraishi, T. Open air photoresist ashing by cold plasma torch: Catalytic effect of cathode material. Appl. Phys. Lett. 1995, 66, 2188. [CrossRef]

11. Brandenburg, R.; Ehlbeck, J.; Stieber, M.V.; von Woedtke, T.; Zeymer, J.; Schluter, O.; Weltmann, K.-D. Antimicrobial treatment of heat sensitive materials by means of atmospheric pressure rf-driven Plasma Jet. Contrib. Plasma Phys. 2007, 47, 72. [CrossRef]

12. Lu, X.; Reuter, S.; Laroussi, M.; Liu, D. Non-Equilibrium Atmospheric Pressure Plasma Jets: Fundamentals, Diagnostics, and Medical Applications; CRC Press: Boca Raton, FL, USA, 2019; ISBN 9781498743631.

13. Fridman, G.; Brooks, A.; Galasubramanian, M.; Fridman, A.; Gutsol, A.; Vasilets, V.; Ayan, H.; Friedman, G. Comparison of direct and indirect effects of non-thermal atmospheric-pressure plasma on bacteria. Plasma Process. Polym. 2007, 4, 370. [CrossRef]

14. Shashurin, A.; Keidar, M.; Bronnikov, S.; Jurjus, R.A.; Stepp, M.A. Living tissue under treatment of cold plasma atmospheric jet. Appl. Phys. Lett. 2008, 93, 181501. [CrossRef]

15. Yan, X.; Zou, F.; Zhao, S.; Lu, X.; He, G.; Xiong, Z.; Xiong, Q.; Zhao, Q.; Deng, P.; Huang, J.; et al. On the Mechanism of Plasma Inducing Cell Apoptosis. IEEE Trans Plasma Sci. 2010, 38, 9. [CrossRef]

16. Xiong, Z.; Cao, Y.; Lu, X.; Du, T. Plasmas in tooth root canal. IEEE Trans Plasma Sci. 2011, 39, 2968. [CrossRef]

17. Zimmermann, J.L.; Shimizu, T.; Boxhammer, V.; Morfill G., E. Disinfection through different textiles using low-temperature atmospheric pressure plasma. Plasma Process. Polym. 2012, 9, 792. [CrossRef]

18. Babaeva, N.; Kushner, M.J. Reactive fluxes delivered by dielectric barrier discharge filaments to slightly wounded skin. J. Phys. D Appl. Phys. 2013, 46, 025401. [CrossRef]

19. Weltmann, K.D.; Kindel, E.; Brandenburg, R.; Meyer, C.; Bussiahn, R.; Wilke, C.; Von Woedtke, T. Atmospheric Pressure Plasma Jet for Medical Therapy: Plasma Parameters and Risk Estimation. Contrib. Plasma to Plasma Phys. 2009, 49, 631. [CrossRef]

20. Ehlbeck, J.; Schnabel, U.; Polak, M.; Winter, J.; Von Woedtke, T.; Brandenburg, R.; Von dem Hagen, T.; Weltmann, K.D. Low temperature atmospheric pressure plasma sources for microbial decontamination. $J$. Phys. D: Appl. Phys. 2011, 44, 013002. [CrossRef]

21. Utsumi, F.; Kjiyama, H.; Nakamura, K.; Tanaka, H.; Mizuno, M.; Ishikawa, K.; Kondo, H.; Kano, H.; Hori, M.; Kikkawa, F. Effect of Indirect Nonequilibrium Atmospheric Pressure Plasma on Anti-Proliferative Activity against Chronic Chemo-Resistant Ovarian Cancer Cells In Vitro and In Vivo. PLoS ONE 2013, 8, e81576. [CrossRef]

22. Tanaka, H.; Mizuno, M.; Ishikawa, K.; Takeda, K.; Nakamura, K.; Utsumi, F.; Kajiyama, H.; Kano, H.; Okazaki, Y.; Toyokuni, S.; et al. Plasma Medical Science for Cancer Therapy: Toward Cancer Therapy Using Nonthermal Atmospheric Pressure Plasma. IEEE Trans. Plasma Sci. 2014, 42, 3760. [CrossRef]

23. Vandamme, M.; Robert, E.; Pesnele, S.; Barbosa, E.; Dozias, S.; Sobilo, J.; Lerondel, S.; Le Pape, A.; Pouvesle, J.-M. Antitumor Effects of Plasma Treatment on U87 Glioma Xenografts: Preliminary Results. Plasma Process. Polym. 2010, 7, 264. [CrossRef]

24. Fridman, G.; Shereshevsky, A.; Jost, M.M.; Brooks, A.D.; Fridman, A.; Gutsol, A.; Vasilets, V.; Friedman, G. Floating electrode dielectric barrier discharge plasma in air promoting apoptotic behavior in melanoma skin cancer cell lines. Plasma Chem. Plasma Process. 2007, 27, 163. [CrossRef]

25. Volotskova, O.; Hawley, T.S.; Stepp, M.A.; Keidar, M. Targeting the cancer cell cycle by cold atmospheric plasma. Sci Rep-Uk 2012, 2. [CrossRef] [PubMed]

26. Brandenburg, R. Dielectric barrier discharges: Progress on plasma sources and on the understanding of regimes and single filaments. Plasma Sources Sci. Technol. 2017, 26, 053001. [CrossRef]

27. Weltmann, K.-D.; Kindel, E.; von Woedtke, T.; Hähnel, M.; Stieber, M.; Brandenburg, R. Atmospheric-pressure plasma sources: Prospective tools for plasma medicine. Pure Appl. Chem. 2010, 82, 1223. [CrossRef]

28. Teschke, M.; Kedzierski, J.; Finantu-Dinu, E.G.; Korzec, D.; Engemann, J. High-speed photographs of a dielectric barrier atmospheric pressure Plasma Jet. IEEE Trans. Plasma Sci. 2005, 33, 310. [CrossRef]

29. Lu, X.; Laroussi, M. Dynamics of an atmospheric pressure plasma plume generated by submicrosecond voltage pulses. J. Appl. Phys. 2006, 100, 063302. [CrossRef]

30. Sands, B.L.; Ganguly, B.N.; Tachibana, K.A. Streamer-like atmospheric pressure plasma jet. Appl. Phys. Lett. 2008, 92, 151503. [CrossRef] 
31. Mericam-Bourdet, N.; Laroussi, M.; Begum, A.; Karakas, E. Experimental investigations of plasma bullets. J. Phys. D Appl. Phys. 2009, 42, 055207. [CrossRef]

32. Naidis, G.V. Modeling of plasma bullet propagation along a helium jet in ambient air. J. Phys. D Appl. Phys. 2011, 44, 215203. [CrossRef]

33. Yousfi, M.; Eichwald, O.; Merbahi, N.; Jomma, N. Analysis of ionization wave dynamics in low-temperature plasma jets from fluid modeling supported by experimental investigations. Plasma Sources Sci. Technol. 2012, 21, 045003. [CrossRef]

34. Boeuf, J.-P.; Yang, L.; Pitchford, L. Dynamics of guided streamer (plasma bullet) in a helium jet in air at atmospheric pressure. J. Phys. D Appl. Phys. 2013, 46, 015201. [CrossRef]

35. Lu, X.; Naidis, G.; Laroussi, M.; Ostrikov, K. Guided ionization waves: Theory and experiments. Phys. Rep. 2014, 540, 123. [CrossRef]

36. Begum, A.; Laroussi, M.; Pervez, M.R. Atmospheric Pressure helium/air plasma Jet: Breakdown processes and propagation phenomenon. AIP Adv. 2013, 3, 062117. [CrossRef]

37. Stretenovic, G.B.; Krstic, I.B.; Kovacevic, V.V.; Obradovic, A.M.; Kuraica, M.M. Spatio-temporally resolved electric field measurements in helium plasma jet. J. Phys. D Appl. Phys. 2014, 47, 102001. [CrossRef]

38. Sobota, A.; Guaitella, O.; Garcia-Caurel, E. Experimentally obtained values of electric field of an atmospheric pressure plasma jet impinging on a dielectric surface. J. Phys. D Appl. Phys. 2013, 46, 372001. [CrossRef]

39. Graves, D. The emerging role of reactive oxygen and nitrogen species in redox biology and some implications for plasma applications to medicine and biology. J. Phys. D: Appl. Phys. 2012, 45, 263001. [CrossRef]

40. Laroussi, M. Low temperature plasma jet for biomedical applications: A review. IEEE Trans. Plasma Sci. 2015, 43, 703. [CrossRef]

41. Lu, X.; Naidis, G.V.; Laroussi, M.; Reuter, S.; Graves, D.B.; Ostrikov, K. Reactive species in non-equilibrium atmospheric pressure plasma: Generation, transport, and biological effects. Phys. Rep. 2016, 630, 1. [CrossRef]

42. Lu, X.; Keidar, M.; Laroussi, M.; Choi, E.; Szili, E.J.; Ostrikov, K. Transcutaneous plasma stress: From soft-matter models to living tissues. Mater. Sci. Eng. R Rep. 2019, 138, 36. [CrossRef]

43. Keidar, M.; Walk, R.; Shashurin, A.; Srinivasan, P.; Sandler, A.; Dasgupta, S.; Ravi, R.; Guerrero-Preston, R.; Trink, B. Cold plasma selectivity and the possibility of a paradigm shift in cancer therapy. Br. J. Cancer 2011, 105, 1295. [CrossRef] [PubMed]

44. Schlegel, J.; Koritzer, J.; Boxhammer, V. Plasma in cancer treatment. Clin. Plasma Med. 2013, 1, 2. [CrossRef]

45. Laroussi, M. Effects of PAM on select normal and cancerous epithelial cells. Plasma Res. Express 2019, 1, 025010. [CrossRef]

46. Gorbanev, Y.; Golda, J.; Gathen, V.; Bogaerts, A. Applications of the COST Plasma Jet: More than a Reference Standard. Plasma 2019, 2, 316. [CrossRef]

47. Teschner, T.; Bansemer, R.; Weltmann, K.; Gerling, T. Investigation of Power Transmission of a Helium Plasma Jet to Different Dielectric Targets Considering Operating Modes. Plasma 2019, 2, 348. [CrossRef]

48. Bolouki, N.; Hsieh, J.; Li, C.; Yang, Y. Emission Spectroscopic Characterization of a Helium Atmospheric Pressure Plasma Jet with Various Mixtures of Argon Gas in the Presence and the Absence of De-Ionized Water as a Target. Plasma 2019, 2, 283. [CrossRef]

49. Simoncelli, E.; Stancampiano, A.; Boselli, M.; Gherardi, M.; Colombo, V. Experimental Investigation on the Influence of Target Physical Properties on an Impinging Plasma Jet. Plasma 2019, 2, 369. [CrossRef]

50. Groele, J.; Foster, J. Hydrogen Peroxide Interference in Chemical Oxygen Demand Assessments of Plasma Treated Waters. Plasma 2019, 2, 294. [CrossRef]

51. Laroussi, M. Ignition of A Plasma Discharge Inside An Electrodeless Chamber: Methods and Characteristics. Plasma 2019, 2, 380. [CrossRef]

52. Laroussi, M. Plasma Medicine: A Brief Introduction. Plasma 2018, 1, 47. [CrossRef]

53. Cheng, X.; Rowe, W.; Ly, L.; Shashurin, A.; Zhuang, T.; Wigh, S.; Basadonna, G.; Trink, B.; Keidar, M.; Canady, J. Treatment of Triple-Negative Breast Cancer Cells with the Canady Cold Plasma Conversion System: Preliminary Results. Plasma 2018, 1, 218. [CrossRef]

54. Bekeschus, S.; Wulf, C.; Freund, E.; Koensgen, D.; Mustea, A.; Weltmann, K.; Stope, M. Plasma Treatment of Ovarian Cancer Cells Mitigates Their Immuno-Modulatory Products Active on THP-1 Monocytes. Plasma 2018, 1, 201. [CrossRef] 
55. Rowe, W.; Cheng, X.; Ly, L.; Zhuang, T.; Basadonna, G.; Trink, B.; Keidar, M.; Canady, J. The Canady Helios Cold Plasma Scalpel Significantly Decreases Viability in Malignant Solid Tumor Cells in a Dose-Dependent Manner. Plasma 2018, 1, 177. [CrossRef]

56. Ly, L.; Jones, S.; Shashurin, A.; Zhuang, T.; Rowe, W.; Cheng, X.; Wigh, S.; Naab, T.; Keidar, M.; Canady, J. A New Cold Plasma Jet: Performance Evaluation of Cold Plasma, Hybrid Plasma and Argon Plasma Coagulation. Plasma 2018, 1, 189. [CrossRef]

57. Crestale, L.; Laurita, R.; Liguori, A.; Stancampiano, A.; Talmon, M.; Bisag, A.; Gherardi, M.; Amoruso, A.; Colombo, V.; Fresu, L. Cold Atmospheric Pressure Plasma Treatment Modulates Human Monocytes/Macrophages Responsiveness. Plasma 2018, 1, 261. [CrossRef]

58. Razzokov, J.; Yusupov, M.; Bogaerts, A. Possible Mechanism of Glucose Uptake Enhanced by Cold Atmospheric Plasma: Atomic Scale Simulations. Plasma 2018, 1, 119. [CrossRef]

59. Tanaka, H.; Mizuno, M.; Ishikawa, K.; Toyokuni, S.; Kajiyama, H.; Kikkawa, F.; Hori, M. New Hopes for Plasma-Based Cancer Treatment. Plasma 2018, 1, 150. [CrossRef]

(C) 2020 by the author. Licensee MDPI, Basel, Switzerland. This article is an open access article distributed under the terms and conditions of the Creative Commons Attribution (CC BY) license (http://creativecommons.org/licenses/by/4.0/). 